\title{
空間分布が軸方向座標のみに依存する軸方向 外部磁気遮蔽用の超電導巻線型磁気シールド
}

\author{
正 員 武 智 盛 明 (三菱電機)
}

\begin{abstract}
Magnetic shielding by superconducting windings for shielding axial external magnetic field with spatial distribution of a function of axial co-ordinates

Moriaki Takechi, Member (Mitsubishi Electric Corporation)
\end{abstract}

\begin{abstract}
This paper describes an analytical study on magnetic shielding by a set of superconducting windings for applications such as low magnetic field measurement using SQUIDs (superconducting quantum interference device) and magnetic resonance imaging. Fundamental equations to be satisfied by the coil system are studied and a direct method to determine coil parameters are proposed. The proposed method was applied to obtain coil configurations for shielding axial external magnetic field with spatial distribution of uniform or linear gradient along axis. Comparison of the shielding factor proves that superconducting windings can achieve better shielding factors than superconducting cylinder with same aspect ratio.
\end{abstract}

キーワード：磁気遮蔽、超電導コイル、磁気雑音、SQUID

\section{1.まえがき}

SQUID(超伝導量子干涉素子)を用いた生体磁気計測など の微弱磁界の計測では、環境磁気雑音に比べて低い磁界の 湘定が必要となるため、環境磁気雑音を遮蔽した低磁界空 間の形成が要求される。また、磁気共鳴メージング装置に 拝いても、磁気共鳴周波数の変動による画質の低下を防止 するため、磁気的外乱の遮蔽が要求される。

このような環境磁気雑音を遮蔽する遮蔽材として、磁性 体や超電導体か利用されている。超電導シールドは、超電 導体の完全反磁性と完全導電性を利用したもので、低周波 に扔いても高い遮蔽効果が得られる特徴を有するため、 $10^{-4} \sim 10^{-5}$ 程度の高い磁気遮蔽率を要求される生体磁気計 測などの、微弱磁界計測用の磁気遮蔽として関心が高まっ ている(1)(2)。

超電導体を用いた磁気シールドとしては、従来、主とし て円筒状超電導体を用いたものが検討されている。円筒状 超電導シールドの内部磁界解析については矢原 ${ }^{(3)} 、 F e n g^{(4)}$ 等の報告があり、一端開放または両端開放の有限長円筒に おいても軸方向磁界に対する遮蔽効果を有することが示さ れている。しかし、軸方向の外部磁界に対して、両端開放 の有限長円筒で高い遮蔽効果を得るためには、円筒の長さ と半径の比を大きくする必要がある。また、部分的な遮蔽 特性の相違や、局所的な磁束トラップを防ぐためには、超 電導材に均質な特性が要求される。従って、広い領域を遮 蔽しうる大型磁気シールドの実現は容易でない。また、遮 蔽効果を高めるために、一端を閉鎖した円筒状シールドも
研究されているが、被験者への圧迫感の緩和や、計器配置 の自由度を確保する観点からは、両端開放、且つ短尺の形 状が望ましい。

一方、超電導卷線による磁気遮蔽作用については、古く から着目されているが(5)、その応用は比較的遮蔽率の低い 対象にとどまっている。また、巻線を用いた外部磁気遮蔽 として、外部磁界を磁界測定素子で検出し、逆極性の磁界 を発生するよう常電導コイルの通電電流を制御する能動型 磁気シールドが報告されているが(6)、高遮蔽率の受動型磁 気シールドは報告例をみない。

超電導巻線による磁気遮蔽は、外部磁界によって巻線に 誘起される電流が発生する逆極性磁界を利用するものであ り、巻線型で高い磁気遮蔽率の磁気シールドが実現できれ ば、超電導円筒シールドと同様、電源を必要としない受動 型の磁気シールドが実現できる。また、超電導線材を巻回 して製作するので、大型装置の製作も可能となる。しか し、超電導卷線で高い磁気遮蔽率を得るためには、誘導電 流によって発生する磁界が、対象とする全領域にわたって 印加磁界と大きさが等しく、逆極性である必要がある。超 電導コイルで所定の磁界分布を得るためのコイル形状の決 定法については、多数の報告があるが、何れも強制電流を 前提としたものであり、コイルの形状と巻数および電流值 は、超電導導体の許容電流密度や、装置の許容寸法等の制 約条件内で、任意に選定できることを前提としている。こ れに対し巻線型磁気シールドでは、巻線電流は外部磁界に よる誘起電流であって、シールドコイルの形状と巻数密 度、および外部磁界によって定まり、任意に選定できな 
い。本論文でも例示するごとく、一般に、外部磁界によっ て超電導コイルに誘起する電流は、印加磁界を相殺するに 必要な電流とは一致しない。このため、巻線型で高い磁気 遮蔽特性を実現し得るか否かについては明らかにされてい ない。

本論文では、超電導線材を用いた巻線型超電導シールド による外部磁気遮蔽の可能性を検討するための第一段階と して、軸方向成分のみを有し、その空間分布が軸方向座標 のみに依存する外部磁界を対象に、巻線型超電導シールド の可能性を検討する。まず、超電導円筒および超電導ソレ ノイドコイルの軸方向外部磁界に対する磁気遮蔽特性を解 析し、無作為の形状では良好な遮蔽特性が得られないこと を示す。次いで、超電導巻線で外部磁界遮蔽を行うための 条件を検討し、所要の遮蔽特性をもつ巻線諸元を決定する ための基本式を導出する。また、この基本式の解を得るた めの陽解法を示す。さらに、この方法を用いて得られた具 体的な巻線型磁気シールドの形状例を示し、超電導巻線を 用いて、短尺で高い磁気遮蔽率を有する磁気シールドが実 現可能であることを示す。

\section{2. 超電導シールドの磁気遮蔽特性}

超電導円筒や超電導コイルは、超電導体の完全導電性ま たは完全反磁性の特性によって、受動的な磁気遮蔽作用を 示す。Feng (4) は有限長の両端開放超電導円筒に軸方向一様 磁界が印加された場合の、軸上に扔ける磁界遮蔽効果を求 めているが、非軸上の遮蔽効果や勾配磁界の遮蔽効果につ いては述べていない。また、Gabrier(5)は超電導単層ソレ ノイドコイルの磁気遮蔽効果を求めているが、シールドコ イルの発生する逆磁界の均一性が問題とならない用途が対 象となっている。何れも、無作為の形状では、微弱磁界計 測などに要求される高い磁気遮蔽率は実現できないことを 示している。そこで、巻線型超電導シールドの実現可能性 を検討するに先立ち、超電導円筒および超電導コイルの磁 気遮蔽特性について考察し、高遮蔽率の磁気シールドの満 たすべき条件を検討する。

$<2.1>$ 超電導円筒の磁気遮蔽特性 有限長の両端開 放超電導円筒に、軸方向磁界が印加される場合の磁気遮蔽 特性について検討する。この場合の誘起電流は周回成分の みを有するので、図1に示す如く、円筒を軸方向に分割し た円環に置換しても電流分布は変化しない。また、円環は 零抵抗閉回路を構成するので、鎖交磁束は変化しない。 従って、半径 $a$ 、長さ $2 l$ の超電導円筒を $n$ 個の円璒に分割 L、円環要素 $i$ の心座標を $z_{i}$ 、誘起電流を $I_{i}$ 、円環要素 $i$ と円環要素 $j の$ 相互インダクタンスを $M_{i j}$ とすれば、次式が 成立する。

$$
\sum_{i=1}^{n} M_{i j} I_{i}+\phi_{i}=0 \quad(i=1,2, \cdots, n)
$$

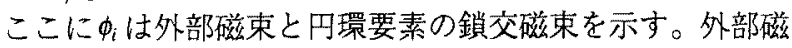
界が軸方向成分のみを有し、円筒座標系で

$$
\mathbf{B}_{\mathbf{e}}(r, z, \varphi)=B_{e z}(r, z, \varphi) \cdot \mathbf{e}_{z}
$$

と表されるものとすれば、诂は次式で与えられる。

$$
\phi_{i}=\int_{0}^{a} \int_{0}^{2 \pi} B_{e z}(r, z, \varphi) r d r d \varphi
$$

(1)(3)式から、超電導円筒に誘起される電流の分布を求め ることができる。

一方、図 2 に示す半径 $a_{i}$ 、電流密度 $j_{i}$ の円環電流による 磁界B 対称磁界であり、 $\rho<a の$ 領域に対し、ルジャンドル関数 $P_{k}$ を用いて次の級数式で表すことができる(7)。

$$
\mathbf{B}_{i}(r, z)=B_{i z}(r, z) \cdot \mathbf{e}_{z}+B_{i r}(r, z) \cdot \mathbf{e}_{r}
$$
ここに

$$
\begin{aligned}
& B_{i z}(r, z)=\sum_{k=0}^{\infty} \frac{\mu_{o} \dot{j}_{i}}{2} \varepsilon_{i k}\left(a_{i}, z_{i}, w_{i}\right)\left(\frac{\rho}{a_{i}}\right)^{k} P_{k}(\cos \theta) \\
& B_{i r}(r, z)=\sum_{k=1}^{\infty} \frac{\mu_{o} j_{i}}{2} \varepsilon_{i k}\left(a_{i}, z_{i}, w_{i}\right)\left(\frac{\rho}{a_{i}}\right)^{k} \frac{P_{k}^{\prime}(\cos \theta)}{k+1}
\end{aligned}
$$
ただし、

$$
\begin{aligned}
& \rho=\sqrt{r^{2}+z^{2}} \\
& \theta=\tan ^{-1} \frac{r}{z}
\end{aligned}
$$

また、係数 $\varepsilon_{i k}$ は、円環電流による磁界の、原点における テイラー展開の係数を与え、円環の形状変数 $a_{i} 、 z_{i} 、 w_{i} に$ よって定まる。その表式を付録1に示す。

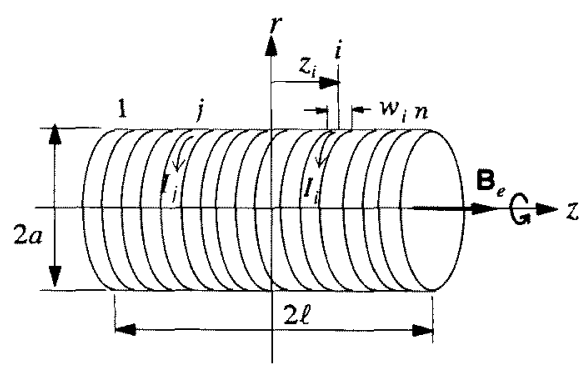

図1 超電導円简シールドの磁気遮蔽率解析モデル

Fig.1 Schematic diagram for analysis of shielding factor of superconducting cylindrical shield

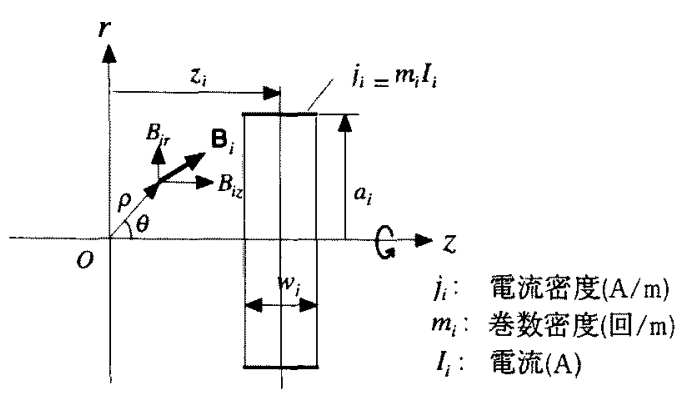

図2 円環要素の磁界計算モデル

Fig.2 Analytical model of single layer solenoid for magnetic field calculation 
超電導円筒に誘起された電流による磁界は、全円環要素 の磁界の合成値として、次式で与えられる。

$$
\begin{aligned}
B_{a z}(r, z) & =\sum_{i=1}^{n} B_{i z}(r, z) \\
& =\sum_{k=0}^{\infty}\left\{\sum_{i=1}^{n} \frac{\mu_{0} j_{i}}{2} \varepsilon_{i k}\left(a_{i}, z_{i}, w_{i}\right)\left(\frac{\rho}{a_{i}}\right)^{k}\right\} P_{k}(\cos \theta) \\
B_{c r}(r, z) & =\sum_{i=1}^{n} B_{i r}(r, z) \\
& =\sum_{k=1}^{\infty}\left\{\sum_{i=1}^{n} \frac{\mu_{0} j_{i}}{2} \varepsilon_{i k}\left(a_{i}, z_{i}, w_{i}\right)\left(\frac{\rho}{a_{i}}\right)^{k}\right\} \frac{P_{k}^{\prime}(\cos \theta)}{k+1}
\end{aligned}
$$

超電導円筒内部の残留磁界 $\mathbf{B}_{r e s}$ は、超電導円筒による磁 界と印加磁界の合成値として求められる。

$$
\mathbf{B}_{r e s}(r, z, \varphi)=\left\{B_{e z}(r, z, \varphi)+B_{c z}(r, z)\right\} \cdot \mathbf{e}_{z}+B_{c r}(r, z) \cdot \mathbf{e}_{r}
$$

超電導円筒の誘起電流による磁界は、 $\varphi$ に依存しない軸対 称磁界であるので、外部磁界の $\varphi$ に依存する分布は、超電 導円筒では相殺できない。そこで、ここでは、外部磁界が $z$ 軸方向成分のみを有し、且つ、その空間分布が $z$ 座標の みの関数である場合について、遮蔽特性を検討する。特に 本項は、超電導円筒の基本的な遮蔽特性を考察することが 目的であるので、zによらず一定の大きさを有する磁界以 下一様磁界と呼ふ)と、大きさが座標に比例して変化する 磁界(以下 $z$ の一次勾配磁界と呼ふ)について検討する。

図3は、 $\| a=1.0$ の形状の超電導円筒に、 $z$ 軸方向の一様 磁界が印加された場合の磁束分布を示したものである。ま た、四4は、この場合の残留磁界と印加磁界の此Bres/Be の軸上分布を求めたものである。(10)式からも明らかな通 り、 $z$ 軸上 $(\theta=0)$ では磁界の径方向成分は零であるので、 Bresは残留磁界のz成分の大きさに等しい。图より、超電 導円筒の中心に执いても、印加磁界の $2.4 \%$ 磁界が残留し ており、中心から離れるに従って残留磁界が增加すること がわかる。図5は、超電導円筒の長さと半径の比 $1 / a$ を変 化させた場合の、原点扔よび $z$ 軸上 $\rho=0.3 a$ の点、およびr



図3一様分布外部磁界に対する超電導円筒の磁束分布

Fig.3 Flux distribution for a superconducting cylinder in uniform external field
軸上 $\rho=0.3 a$ の点におりる残留磁界の $z$ 成分と印加磁界の比 を示したものである。 $z$ 軸上抢よび $r$ 軸上では、残留磁界 は $r$ 成分を持たないので、诚分が残留磁界の大きさを表 す。超電尊円筒の半径を $0.5 \mathrm{~m}$ とし、磁気遮蔽の対象領域と して $\rho \leq 0.15 m$ の領域を想定すれば、对象領域の残留磁界を 印加磁界の $10^{-5}$ 以下とするためには $l>3 a$ すなわち超電導 円筒の全長を $3 m$ 以上とする必要のあることがわかる。

$<2.2>$ 超要䇝巻線の磁気遮蔽特性次に超電導巻線の 磁気遮蔽特性について考察する。超電導巻線系は、同軸に 配置した $n$ 個の円筒状コイルを直列接続して、閉回路が構 成されているものとする。巻線 $i$ と外部磁束 $\mathbf{B}_{e}$ との鎖交磁 束を $\lambda_{i}$ 、誘起電流を $\Delta I$ 、巻線系の合成インダクタンスを $L$ とすれば、鎖交磁束保存の条件から次式が成立する。

$$
L \cdot \Delta I+\sum_{i=1}^{n} \lambda_{i}=0
$$

(12)式より誘起電流を求めれば(11)式から残留磁界を求め ることができる。

図6は、半径 $a$ 長さ $2 l$ の単層ソレノイドコイルについ て、z軸方向に一様磁界が印加された場合の、コイル中心 に扔计る残留磁界の印加磁界に対する比、Bres/Beを求め たものである。残留磁界は、ソレノイドコイルの形状比 l/akよって異なり、特定の形状、即ち $\| a=0.876$ の場合 のみ、中心における残留磁界が零となることがわかる。

図7は、この場合の磁束分布を示したものである。ま た、図8は軸上残留磁界を示す。中心においては誘起磁界 が印加磁界を相殺し、残留磁界が零となるが、中心以外の 点では磁界が残留し、 $z / a=0.3$ の点におけ当残留磁界は、

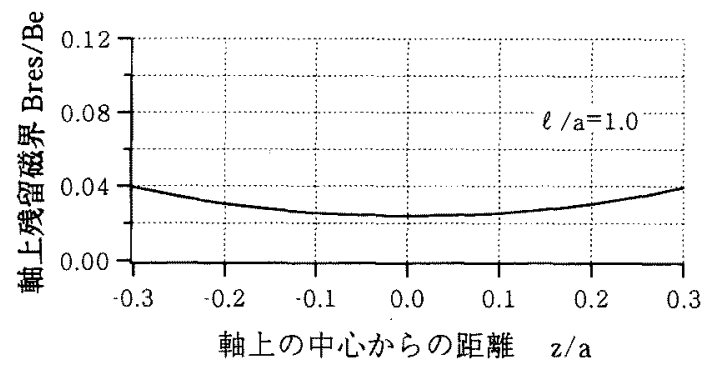

図4一栚分布外部磁界に対する超電尊円筒の軸上残留磁界

Fig.4 Axial distribution of residual field for a superconducting cylinder in uniform external field

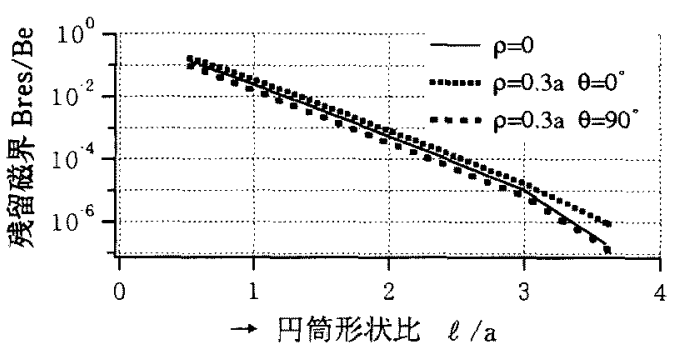

図5一様磁界に対する超電尊円筒シールドの磁気遮蔽特性

Fig.5 Shielding factor of a superconducting cylindrical shield for uniform field 
印加磁界の0.0434である。これは、ソレノイドコイルの誘 起電流によって発生する逆磁界が、空間的に均一でないた めである。一様磁界に対して広い領域で高い遮蔽効果を得 るためには、コイルの誘起電流による発生磁界が、空間的 に均一であることが要求される。そこで、高均一磁界発生 用マグネットの磁気遮蔽効果を試算する。

図9は、0.5T 高均一磁界発生用超電導マグネットのコイ ル諸元例を示したものである。このコイルについて、軸方 向一㥞磁界印加時の磁界分布を求めると、図10拈上び図 11 の通りであり、印加磁界の 0.286 に相当する大きな磁界

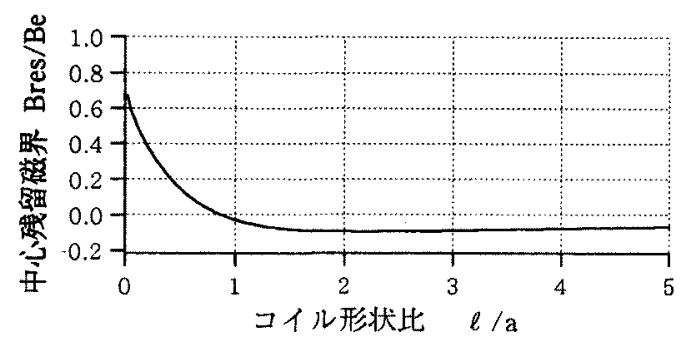

図6 超電導単層ソレノイドコイルの中心残留磁界

Fig.6 Residual field at the center of superconducting single layer solenoid

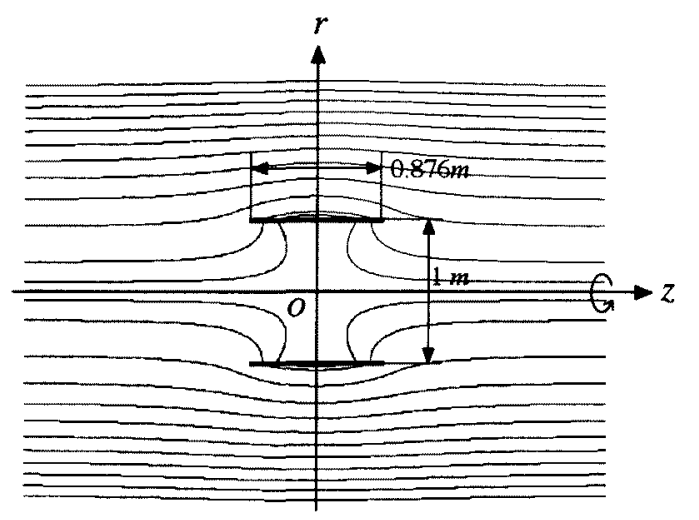

図7一様分布外部磁界に対する単層ソレノイド コイルの磁束分布

Fig.7 Flux distribution for a single layer solenoid in uniform external field

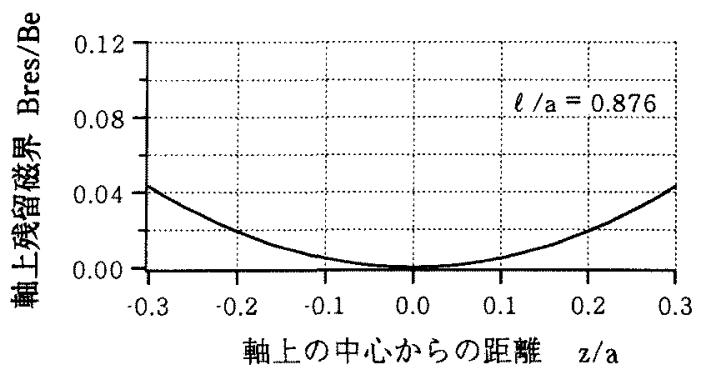

図8一様分布外部磁界に対する超電導単層ソレノイド コイルの軸上残留磁鱼

Fig.8 Axial distribution of residual field for a superconducting single layer solenoid in uniform external field

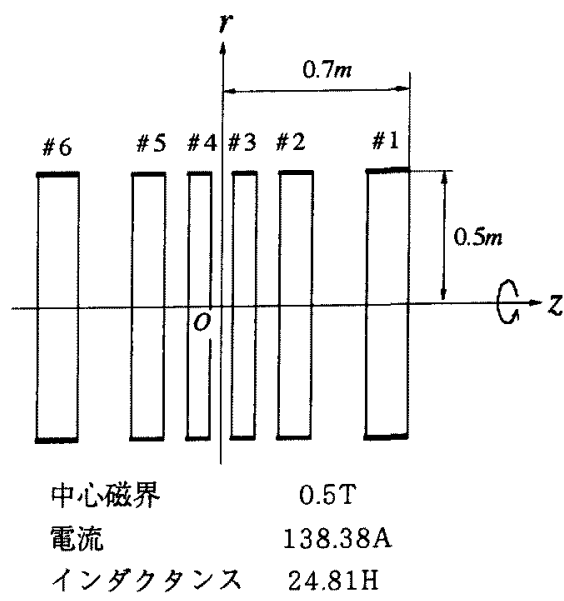

\begin{tabular}{|c|c|c|c|c|c|}
\hline \multirow[t]{2}{*}{ コイル番号 } & \multirow[t]{2}{*}{ 巻数 } & \multicolumn{4}{|c|}{ "コイル中心座標 コイル厚さコイル長さ } \\
\hline & & $z(\mathrm{~m})$ & $\mathrm{r}(\mathrm{m})$ & (m) & (m) \\
\hline$\# 1, \# 6$ & 1830 & 0.6213 & 0.50 & 0.01 & 0.1575 \\
\hline$\# 2, \# 5$ & 725 & 0.2785 & 0.5025 & 0.005 & 0.1212 \\
\hline$\# 3, \# 4$ & 520 & 0.0831 & 0.5025 & 0.005 & 0.0853 \\
\hline
\end{tabular}

図9高均一磁界発生マグネットの磁気遮蔽率解析モデル Fig.9 Analytical model for calculation of shielding factor of a high homogeneity magnet



図 10 一様分布外部磁界に対する高均一磁界発生用 マグネットの磁束分布

Fig.10 Flux distribution for a high homogeneity magnet in uniform external field

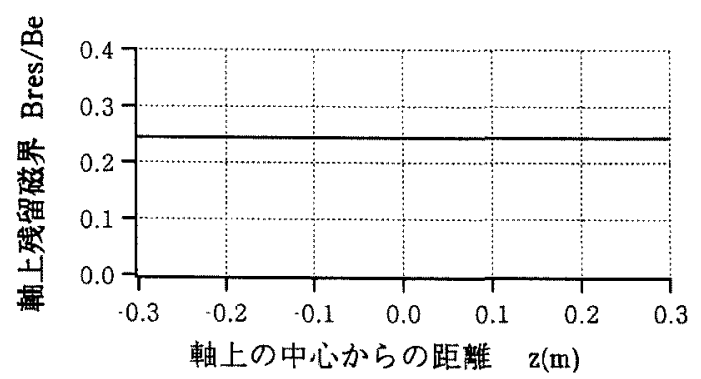

図11一様分布外部磁界に対する高均一磁界マグネット の軸上残留磁界

Fig.11 Axial distribution of residual field for a high homogeneity magnet in uniform external field 
が残留する。これは、外部磁界による誘起電流が、印加磁 界を相殺するには不足するためである。本例では、 $0.5 T$ の 磁界を発生するに要する電流が138.38Aであるのに対し、 $0.5 T$ の軸方向一梯磁界が印加された場合の鎖交磁束は $2.45 \times 10^{3} \mathrm{~Wb}$ 、誘起電流は $98.9 A$ であり、0.5Tの外部磁界を 相殺しうる電流には達しない。高均一磁界マグネットで は、誘起電流によって、広い空間にわたって一梯な逆磁界 を発生するが、逆磁界が印加磁界を相殺するには不足し、 高い遮蔽効果が得られないことがわかる。

\section{3. 巻線型超電導シールドの基本式}

前章の考察により、通常の超電導巻線では、高い遮蔽率 が得られず、また、シート状超電導体を用いた超電導円筒 でも、軸方向外部磁界に対する遮蔽率は、円筒の長さに依 存し、高い遮蔽率を得るためには、長尺の円筒が必要であ ることが明らかとなった。そこで、巻線型超電導シールド による高遮蔽率の可能性と条件を検討する。

\section{$<3.1>$ 外部磁界の条件磁気遮蔽の対象となる環境} 磁界は、一般に三軸方向の成分を有し、その各軸成分も空 間座標の関数となるが、本稿では、検討の第一段階とし て、一軸 $(z$ 軸 $)$ 方向の成分のみを有し、且つ、その空間分 布がz座標のみに依存する外部磁界を対象とする。三軸方 向の遮蔽は、原理的には、本稿の一軸遮蔽を組み合わせる ことによって可能である。また、外部磁界が一軸成分のみ の場合でも、その空間分布が、軸方向座標のみでなく、径 方向、周方向座標に依存する場合は、本稿とは異なる構成 の磁気シールドが必要となる。なお、磁気共鳴イメージン グ装置などのように、外部磁界に比へて高い一軸方向磁界 を発生している装置では、軸と直角方向の外部磁界成分 が、磁界の絶対値に与える影響は小さいので、通常、一軸 方向のみの遮蔽が要求される。

$<3.2>$ 巻線型超電導シールドの構成と動作 超電導 シールドは、図12の如く、超電導線を巻回した複数の同軸 円筒状ソレノイドコイルで構成され、コイルはすべて直列



図12 卷線型磁気シールドの構成

FiG.12 Shcematic diagram of magnetic shielding with superconducting windings
接続されているものとする。さらに、コイル両端の端子間 には永久電流スイッチを接続して、コイル系を短絡または 開放できる構成とする。

永久電流スイッチを開路した状態で、コイル系を超電導 状態とし、コイル系を零磁界空間に保持した状態で、永久 電流スイッチを閒路するものとする。コイル系は零抵抗閉 回路を構成するので、鎖交磁束が保存される。従って、外 部から磁界が印加されると、コイル系には鎖交磁束の変化 を妨げるよう電流が誘起される。外部磁界によるコイル系 の中心部の磁界変動は、コイル系の誘起電流によって発生 する磁界と印加磁界との合成值で与えられる。この合成磁 界がマグネット中心部で無視できる值となるようコイル系 の定数を定めることが出来れば、外部磁気遮蔽用のコイル 系を実現することが出来る。

<3.3> 巻線型超電導シールドの基本方程式 外部磁 界は $z$ 軸方向成分のみを有し、その空間分布は $z$ 座標のみ の関数で、 $z の$ 多項式で表されるものとする。また、5章 の解析例に示す如く、磁気遮蔽に必要なアンベアターンは 比較的少なく、コイル厚さは直径に比し無視できる形状と なるので、以下、コイルの厚みは無視できるものとする。 このとき、外部磁界は、円筒座標系を用いて、次の様に表 される。

$$
\begin{aligned}
\mathbf{B}_{e}(r, z) & =B_{e z}(r, z) \cdot \mathbf{e}_{z}=B_{e z}(z) \cdot \mathbf{e}_{z} \\
& =\left\{\sum_{k=0}^{\infty} B_{k}\left(\frac{z}{d}\right)^{k}\right\} \cdot \mathbf{e}_{z}
\end{aligned}
$$

ここに、 $B_{k}(k=0,1, \cdots)$ は、 $z$ $k$ 次成分の $z=d に お け る$ 值で ある。

コイルiの諸元を図2のごとく仮定すれば、コイル $i$ と印加 磁界 $\mathbf{B}_{e}$ との鎖交磁束 $\lambda_{i}$ は次式で与えられる。

$$
\begin{aligned}
\lambda_{i} & =\int_{a_{1}}^{a_{i 2}} \int_{z_{i}-w_{i} / 2}^{z_{i}+w_{i} / 2} m_{i} d r d z 2 \pi r B_{e z}(z) \\
& =m_{i} \phi_{i} \\
\text { たたし、 } & m_{i} \text { はコイルiの巻数密度とし、 } \\
\phi_{i} & =\sum_{k=0}^{\infty} \pi a_{i}^{2} B_{k} \int_{z_{i}-w_{i} / 2}^{z_{i}+w_{i} / 2}\left(\frac{z}{d}\right)^{k} d z
\end{aligned}
$$

とする。

また、コイル系の合成インダクタンス $L$ は、次式で与えら れる。

$$
L=\sum_{i=1}^{n} \sum_{j=1}^{n} K_{i, j} m_{i} m_{j}
$$

ただし、 $K_{i, j}$ は、コイルの形状と配置のみで定まる定数で ある。

(12) （16)式より、誘起電流の条件として、次式を得る。

$$
\Delta I \sum_{i=1}^{n} \sum_{j=1}^{n} K_{i, j} m_{i} m_{j}+\sum_{i=1}^{n} m_{i} \phi_{i}=0
$$

次に、誘起電流 $\Delta I$ により発生する磁界を求める。各コ イルの通電電流は全て等しく 流密度は $m_{i} \Delta l$ で与えられる。円筒状コイルが発生する磁界 が(4)〜(8)式で与えられることを考慮すれば、コイル系の 
発生する磁界 $\mathbf{B}_{c}(r, z)$ は、各コイルの磁界出力の和として 次式で与えられる。

$$
\begin{aligned}
& \mathbf{B}_{c}(r, z)=\sum_{k=0}^{\infty}\left\{\sum_{i=1}^{n} \frac{\mu_{0} m_{i} \Delta I}{2} \varepsilon_{i k}\left(a_{i}, z_{i}, w_{i}\left(\frac{\rho}{a_{i}}\right)^{k}\right\} P_{k}(\cos \theta) \cdot \mathbf{e}_{z}\right. \\
& +\sum_{k=1}^{\infty}\left\{\sum_{i=1}^{n} \frac{\mu_{0} m_{j} \Delta I}{2} \varepsilon_{i k}\left(a_{i}, z_{i}, w_{i}\right)\left(\frac{\rho}{a_{i}}\right)^{k}\right\} \frac{P_{k}^{\prime}(\cos \theta)}{k+1} \cdot \mathbf{e}_{r} \\
& =\sum_{k=0}^{\infty} b_{k}(\rho) \cdot P_{k}(\cos \theta) \cdot \mathbf{e}_{z}+\sum_{k=1}^{\infty} b_{k}(\rho) \cdot \frac{P_{k}^{\prime}(\cos \theta)}{k+1} \cdot \mathbf{e}_{r} \\
& \begin{array}{l}
\rho=\sqrt{r^{2}+z^{2}} \\
\theta=\tan ^{-1} \frac{r}{z} \\
b_{k}(\rho)=\sum_{i=1}^{n} \frac{\mu_{0} m_{i} \Delta l}{2} \cdot \varepsilon_{k}\left(a_{i}, z_{i}, w_{i}\right) \cdot\left(\frac{\rho}{a_{i}}\right)^{k}
\end{array}
\end{aligned}
$$$$
\text { ただし }
$$

(13)式で与えられる外部磁界 $\mathbf{B}_{e}(r, z)$ が印加された場合の 残留磁界 $\mathbf{B}_{r e s}(r, z)$ は、外部磁界とコイル磁界の和として次 式で与えられる。

$$
\begin{aligned}
\mathbf{B}_{r e s}(r, z)=\sum_{k=0}^{\infty} & \left\{B_{k}\left(\frac{z}{d}\right)^{k}+b_{k}(\rho) \cdot P_{k}(\cos \theta)\right\} \cdot \mathbf{e}_{z} \\
& +\sum_{k=1}^{\infty} b_{k}(\rho) \cdot \frac{P_{k}^{\prime}(\cos \theta)}{k+1} \cdot \mathbf{e}_{r}
\end{aligned}
$$

$<3.4>$ 偶数次磁界の遮蔽条件 (22)式をもとに、外部

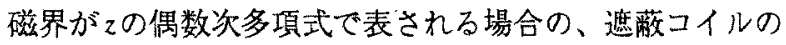
条件を検討する。遮蔽コイルは、 $z=0$ 面に対称に配置さ れた $n$ 対のコイル群で構成するものとする。中心点近傍で 残留磁界が零となるためには(22)式で与えられる残留磁界 の展開式の各次係数が零となればよい。コイル対数を $n$ と し0次から $2(n-2)$ 次までの係数を零とするものとする。 $z=d に$ に打る2 $(n-2)$ 次までの磁界係数の消去条件から

$$
\begin{aligned}
& \sum_{i=1}^{n} \mu_{0} m_{i} \Delta l \cdot \varepsilon_{0}\left(a_{i}, z_{i}, w_{i}\right)+B_{0}=0 \\
& \sum_{i=1}^{n} \mu_{0} m_{i} \Delta l \cdot \varepsilon_{2}\left(a_{i}, z_{i}, w_{i}\right)\left(\frac{d}{a_{i}}\right)^{2}+B_{2}=0 \\
& \vdots \\
& \sum_{i=1}^{n} \mu_{0} m_{i} \Delta l \cdot \varepsilon_{2 n-4}\left(a_{i}, z_{i}, w_{i}\right)\left(\frac{d}{a_{i}}\right)^{2 n-4}+B_{2 n-4}=0
\end{aligned}
$$

また、誘起電流の条件加ら

$$
\Delta I \sum_{i=1}^{n} \sum_{j=1}^{n} K_{i, j} m_{i} m_{j}+\sum_{i=1}^{n} m_{i} \phi_{i}=0
$$

(23)〜(26)式を満たすよう、コイル系の定数を定めれば よい。

$<3.5>$ 奇数次磁界の遮蔽条件 $\quad 2$ の奇数次多項式で表 される外部磁界に対する遮蔽コイルを、 $z=0$ 面に対称に 配置され、逆極性の $n$ 対のコイル群で構成するものとす る。この時 $z=d に$ に扔ける磁界の消去条件および誘起電流 の条件から以下の条件式がえられる。

$$
\begin{aligned}
& \sum_{i=1}^{n} \mu_{0} m_{i} \Delta l \cdot \varepsilon_{1}\left(a_{i}, z_{i}, w_{i}\right)\left(\frac{d}{a_{i}}\right)^{1}+B_{1}=0 \\
& \sum_{i=1}^{n} \mu_{0} m_{i} \Delta l \cdot \varepsilon_{3}\left(a_{i}, z_{i}, w_{i}\right)\left(\frac{d}{a_{i}}\right)^{3}+B_{3}=0 \\
& \vdots \\
& \sum_{i=1}^{n} \mu_{0} m_{i} \Delta l \cdot \varepsilon_{2 n-3}\left(a_{i}, z_{i}, w_{i}\right)\left(\frac{d}{a_{i}}\right)^{2 n-3}+B_{2 n-3}=0 \\
& \Delta I \sum_{i=1}^{n} \sum_{j=1}^{n} K_{i, j} m_{i} m_{j}+\sum_{i=1}^{n} m_{i} \phi_{i}=0
\end{aligned}
$$

(27)〜(30)式を満たすよう、コイル系の定数を定めれば 上い。

\section{4. 基本方程式の求解法}

(23) 〜 (26)および(27) （30)式は、コイルの形状変数 $a_{i}, z_{i}, w_{i}$ および巻線密度 $m_{i}(i=1 \cdots n)$ に関する多元非線形連 立方程式である。(23) （25)式および(27)～(29)式は、多 分割コイルの誤差磁界消去の条件式であり、磁気共鳴イ メージング装置用などの高均一磁界発生用コイルの求解に 用いられるものと同じである。しかし、巻線型磁気シール ドの巻線電流は、外部磁界との鎖交磁束によって定まる誘 導電流であって、誘導電流に関する条件式(26)又は(30)式 が付加されるので任意に選定できない。従って、巻線電流 を与える鎖交磁束条件式(26)または(30)式と、誤差磁界消 去条件式(23)～(25)式または(27)（29)式を連立させる必 要のある点が、高均一磁界発生用コイルの求解と著しく相 違する点である。特に、高均一磁界発生用コイルの求解で は、コイル形状変数 $a_{i}, z_{i}, w_{i}$ を固定し、コイル電流密度 $m_{i} \Delta I$ のを未知変数とすれば、基本方程式は線形代数方 程式となるのに対し、巻線型磁気シールドでは、誘導電流 に関する条件式が付加されるため、コイル電流密度のみを 未知変数とする場合でも非線形方程式となる。このため、 解の存在領域は、誤差磁界の消去条件のみの場合に比べて 更に狭まり、ニュートンラフソン法などの反復解法による 求解は容易でない。

しかし、(23) (26)式は $m_{i}(i=1 \cdots n) に$ 関する $n-1$ 個の 一次式と1個の二次式で構成されているので、この点に着 目すれば、巻線密度を未知変数とする陽的な求解が可能で ある。この方法によれば、任意のコイル形状変数 $a_{i}, z_{i}, w_{i}$ に対して、遮蔽条件を満たす巻線密度の求解が、反復計算 を行うことなく可能となり、また、実数解の有無について 判別式が得られるので、解の探索を効率的に実施できる。 以下、この手法による基本方程式の求解法を述べる。なお 基本式は偶数次外部磁界と奇数次外部磁界の何れに対して も同一形式であるので、偶数次外部磁界に対する基本式 (23) 〜(26)式について説明する。

$$
\begin{gathered}
\text { (23) } \sim(26) \text { 式において } \\
X_{i}=m_{i} \Delta I
\end{gathered}
$$

とおき $X_{i}$ を末知数とすれば(23)〜 (25))式は $X_{i}(i=1 \cdots n) に$ 関する一次式であり、次の様に表すことができる。 


$$
\begin{gathered}
{\left[\begin{array}{cccc}
h_{0,1} & h_{0,2} & \cdots & h_{0, n-1} \\
h_{2,1} & h_{2,2} & & h_{2, n-1} \\
\vdots & & \ddots & \vdots \\
h_{2 n-4,1} & h_{2 n-4,2} & \cdots & h_{2 n-4, n-1}
\end{array}\right]\left[\begin{array}{c}
X_{1} \\
X_{2} \\
\vdots \\
X_{n-1}
\end{array}\right]+\left[\begin{array}{c}
h_{0, n} \\
h_{2, n} \\
\\
h_{2 n-4, n}
\end{array}\right] X_{n}} \\
=\left[\begin{array}{c}
-B_{0} \\
-B_{2} \\
\vdots \\
-B_{2 n-4}
\end{array}\right]
\end{gathered}
$$

ただし

$$
h_{k, i}=\mu_{0} \varepsilon_{k}\left(a_{i}, z_{i}, w_{j}\right)\left(\frac{d}{a_{i}}\right)^{k}
$$

又、誘導電流の条件式(26)式は、 $X_{i}(i=1 \cdots n)$ に関する二 次形式で、次の様に表すことができる。

$$
\begin{gathered}
{\left[\begin{array}{llll}
X_{1} & X_{2} & \cdots & X_{n}
\end{array}\right]\left[\begin{array}{cccc}
K_{1,1} & K_{1,2} & \cdots & K_{1, n} \\
K_{2,1} & K_{2,2} & \cdots & K_{2, n} \\
\vdots & \vdots & \ddots & \vdots \\
K_{n, 1} & K_{n, 2} & \cdots & K_{n, n}
\end{array}\right]\left[\begin{array}{c}
X_{1} \\
X_{2} \\
\vdots \\
X_{n}
\end{array}\right]} \\
+\left[\begin{array}{llll}
\phi_{1} & \phi_{2} & \cdots & \phi_{n}
\end{array}\right]\left[\begin{array}{c}
X_{1} \\
X_{2} \\
\vdots \\
X_{n}
\end{array}\right]=0
\end{gathered}
$$

(32)式より、 $X_{1}, X_{2} ， \cdots X_{n-1}$ は $X_{n}$ の一次式で与えられるの で、これを(34)式に代入して展開することにより、(34)式 は、一変数 $X_{n}$ に関する次の2次方程式に帰着される(付録 $2)$

$$
A X_{n}{ }^{2}+B X_{n}+C=0
$$

(35)式は下記の判別式が非負の時、実根を有する。

$$
D=B^{2}-4 A C \geq 0
$$

判別式が非負の時、(35)式より $X_{n}$ を求めれば、これを (32)式に代入することにより $X_{1}, X_{2}, \cdots X_{n-1}$ が求められる。

以上の通り、コイルの形状と配置を定めると、遮蔽条 件を満たす巻数の実数解の有無は、(36)式を用いて直ちに 判別することができ、巻数比を(35)及び(32)式で求めるこ とができる。

以上の陽解法によって得られる巻線密度は、一般に整 数比の条件を満たさないので、各コイルの巻数が整数と なる解を得るためには、改めて整数比条件を渵たす解を 求める必要がある。このため、上記の解法で得られた卷 数密度に近い整数比の巻線密度を既知定数とし、新たに 各コイルの中心 $、$ とコイル電流 $I$ 末知変数として求解す る。前述の解法により近似解が得られているため、 ニュートンラフソン法により容易に収束解が得られる。

なお、本稿では、厚みを無視できるソレノイドコイル に対する表式を用いたが、矩形断面コイルの場合でも、 矩形断面に対する磁界の展開係数を用いることにより、 本稿の手法がそのまま適用できる。

\section{5. 解析例}

$<5.1>$ 一様分布軸方向磁界遮蔽 $z$ の偶数次多項式 で与えられる外部磁界に対する巻線型超電導シールドの一 例として、磁界の大きさが位置によらない一様分布の軸方 向磁界に対する巻線型超電導シールドを検討する。巻線 を、 $z=0$ 面に対称に配置された、4対の同極性コイル対で 構成し、各コイルの巻数密度を未知変数とすれば、0次、 2次、4次の残留磁界を消去することができる。

コイル諸元の一例を、第1表および図13に示す。各コイ ルのアンペアターンは、1 $m T$ の外部磁界に対する值を示し ている。磁気遮蔽の対象とする環境磁界変動を $0.1 m T$ とす れば、誘起電流は0.1アンペア程度であり、既存の超電導 線材を用いて容易に実現できる諸元であることがわかる。

図14は、原点近傍における残留磁界の、印加磁界に対 する比Bres/Beを示す。半径 $0.15 \mathrm{~m}$ の球面上の最大值は $\theta=90^{\circ}$ で生し、その值は $0.438 \times 10^{-5}$ 、すなわち $1 / 10^{5}$ 以上 の遮蔽率が得られることがわかる。また、第2 表は、 $z=0.15 m$ における残留磁界の成分を示している。また、図 15は磁束分布を示し、コイル径の中心部では、磁束が排 除されることを示している。

本例の4対コイルで構成される超電導巻線型磁気シール ドの形状比は、 $l / a=1.32$ に相当する。同一形状比の超電 導円筒の磁気遮蔽効果は、図5から0.0124であり、超電導

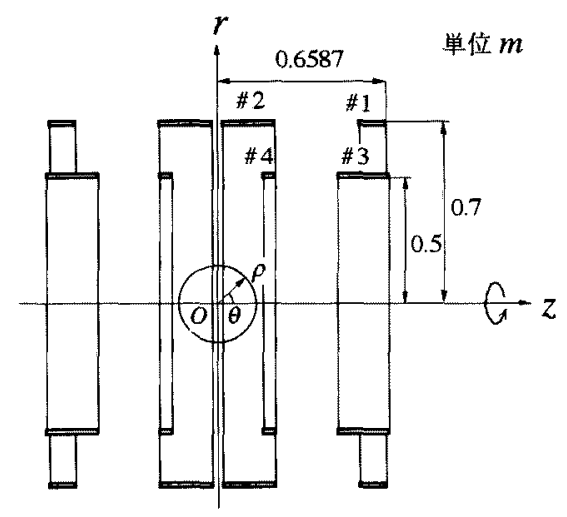

図13一様磁界遮蔽用4対コイル磁気シールドのコイル 配置例

Fig.13 Example of coil configulation of four pairs coil system for shielding uniform external field

\section{第1表 一棁磁界遮蔽用 4 対コイルの諎元例}

Table 1 Example of coil parameters of four pairs coil system for uniform field shielding

\begin{tabular}{cccccc}
\hline コイル & $\begin{array}{c}\text { 半径 } a_{i} \\
(\mathrm{~m})\end{array}$ & $\begin{array}{c}\text { 中心 } \\
(\mathrm{m})\end{array}$ & $\begin{array}{c}\text { 長さ } w_{i} \\
(\mathrm{~m})\end{array}$ & $\begin{array}{c}\text { 巻数 } \\
\text { \#1 }\end{array}$ & $\begin{array}{c}\text { 誘起電流 } \\
(\mathrm{A} / \mathrm{mT})\end{array}$ \\
\hline 2 & 0.70 & 0.59319 & 0.10 & 99 & -0.99886 \\
$\# 3$ & 0.50 & 0.12000 & 0.20 & 309 & -0.99886 \\
$\# 4$ & 0.50 & 0.19819 & 0.05 & 53 & -0.99866 \\
\hline
\end{tabular}


円筒式シールドに比べて超電導巻線型シールドは、短尺 で高い遮蔽効果を実現できることがわかる。

<5.2> zの一次勾配分布軸方向磁界遮蔽 zの奇数 次多項式で与えられる外部磁界に対する巻線型超電導 シールドの一例として、z座標に比例した一次勾配分布の 軸方向磁界に対する超電導巻線型シールドを検討する。 巻線は $z=0$ 面に対称に配置された逆極性の4対コイルで 構成するものとすれば、1次、3次、5次の残留磁界成分 を消去することができる。解析例を図16及び第3表に示 す。また第 4 表は、 $z=0.15 m$ における残留磁界の成分を示 している。

図17は、原点近傍に拈ける残留磁界の、印加磁界に対 する比、Bres/Beを示す。半径 $0.15 \mathrm{~m}$ の球面上の最大值 は、 $\theta=0^{\circ}$ で生じ、その值は $0.843 \times 10^{-5}$ である。すなわ ち、1/10 5 以上の遮蔽率が得られることがわかる。

本例の4対コイルで構成される超電導巻線型磁気シール ドの形状比は、 $l / a=1.49$ に相当する。同一形状比の超電 導円筒の磁気遮蔽効果は0.0403であり、超電導巻線型 シールドは、 $z$ の一次勾配磁界に対しても、超電導円筒式 シールドに比べて短尺で高い遮蔽効果を実現できること がわかる。

<5.3> 複合磁界遮蔽〈5.1)項で得られた一様分布の 軸方向磁界遮蔽用コイルは、 $z=0$ 面に対し、空間的に対 称、かつ同極性のコイルで構成しているので、 配分布の軸方向磁界に対しては、鎖交磁束が相殺して、

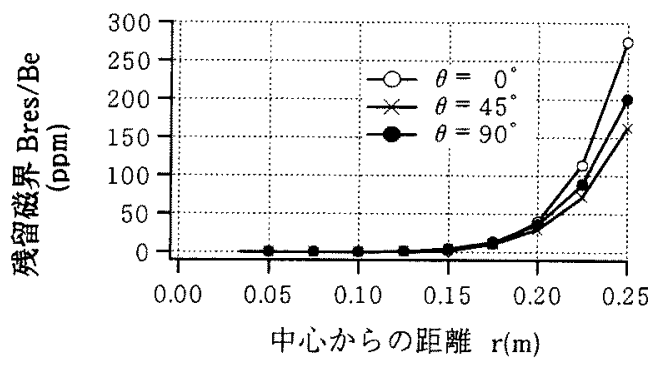

図14一様磁界遮蔽用 4 対コイル磁気シールドの残留磁界 (Bres/Be)

Fig.14 Residual field (Bres/Be) of four pairs coil system for shielding uniform magnetic field
電流を誘起しない。すなわち、 は、遮蔽効果をもたない。一方、45.2、項で得られた巻線 は、 $z=0$ 面に対して空間的に対称であるが、逆極性のコ イルで構成しているので、一様磁界に対しては鎖交磁束 が相殺して、電流を誘起せず、遮蔽効果をもたない。し かし、一様磁界遮蔽用コイルと $z$ の次勾配磁界遮蔽用コ イルを同時に装着すれば、一様磁界とzの一次勾配磁界が 複合した磁界に対しても、遮蔽効果を得ることができ る。zの一次勾配磁界遮蔽用コイルは、 $z=0$ 面に対して逆 極性のコイルで構成しているので、一様磁界遮蔽用コイ ルと同時に適用しても、一様磁界遮蔽コイルとは磁気結 合をもたない。従って、一㥞磁界遮蔽コイルの誘起電流 は、zの一次勾配磁界遮蔽コイルの動作に影響せず、互い に独立に動作する。従って、一様磁界にzの一次勾配磁界 が重畳し、各々独立に時間変動をする複合磁界に対して も遮蔽効果をもたせることができる。

\section{6. むすび}

環境磁気雑音低減のための外部磁界遮蔽装置として超電 導巻線型磁気シールドを提案した。外部磁界として、軸方 向成分のみを有し、その空間分布が軸方向座標の多項式で 表される磁界を対象に、磁気遮蔽の条件と、コイル定数の

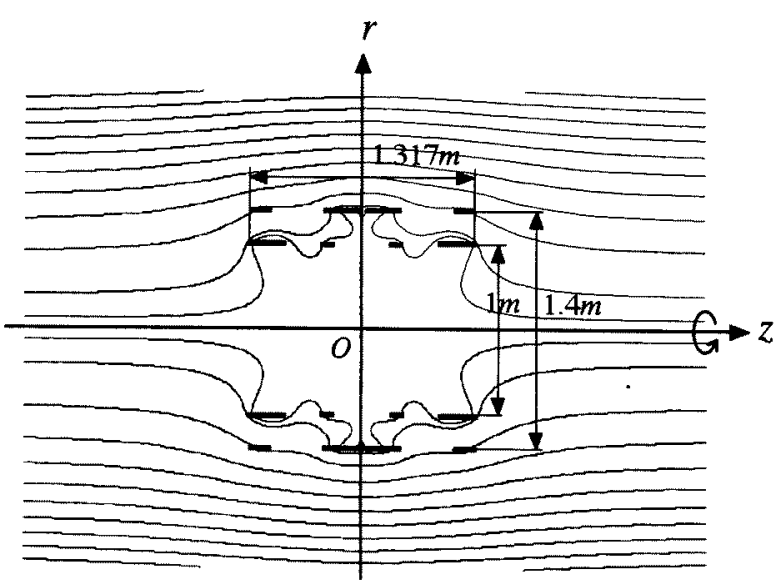

図15一様磁界遮蔽用4対コイル磁気シールドの磁束分布

Fig.15 Flux distribution of four pairs coil system for shielding uniform external field

第2表一様磁界遮蔽用4対コイルの残留磁界 $(\Delta \mathrm{Bres} / \Delta \mathrm{Be})$

軸上 $2=0.15 \mathrm{~m}$ における残留磁界の印加磁界に対する比

Table 2 Residual field ( $\Delta$ Bres $/ \Delta B e$ ) at $z=0.15 \mathrm{~m}$ of four pairs coil system

\begin{tabular}{crrrrrrr}
\hline \hline コイル & \multicolumn{1}{c}{ 2次成分 } & \multicolumn{1}{c}{ 4次成分 } & \multicolumn{1}{c}{ 6次成分 } & \multicolumn{1}{c}{ 8次成分 } & \multicolumn{1}{c}{ 10次成分 } & 12次成分 & 合成值 \\
\hline$\# 1$ & $-3.38 \mathrm{E}+00$ & $1.25 \mathrm{E}-01$ & $2.29 \mathrm{E}-03$ & $-1.39 \mathrm{E}-04$ & $-5.78 \mathrm{E}-07$ & $1.23 \mathrm{E}-07$ & \\
$\# 2$ & $4.54 \mathrm{E}+01$ & $-1.78 \mathrm{E}+00$ & $4.91 \mathrm{E}-02$ & $-4.72 \mathrm{E}-04$ & $-5.07 \mathrm{E}-05$ & $4.53 \mathrm{E}-06$ \\
$\# 3$ & $-5.71 \mathrm{E}+01$ & $7.97 \mathrm{E}-01$ & $1.40 \mathrm{E}-01$ & $-1.30 \mathrm{E}-03$ & $-2.89 \mathrm{E}-04$ & $3.10 \mathrm{E}-06$ & \\
$\# 4$ & $4.28 \mathrm{E}+00$ & $6.43 \mathrm{E}-01$ & $-1.20 \mathrm{E}-01$ & $1.02 \mathrm{E}-02$ & $-3.84 \mathrm{E}-04$ & $-2.47 \mathrm{E}-05$ & \\
\hline 合計 & $0.00 \mathrm{E}+00$ & $0.00 \mathrm{E}+00$ & $6.17 \mathrm{E}-06$ & $8.50 \mathrm{E}-06$ & $5.47 \mathrm{E}-07$ & $1.86 \mathrm{E}-08$ & $1.77 \mathrm{E}-06$ \\
\hline
\end{tabular}




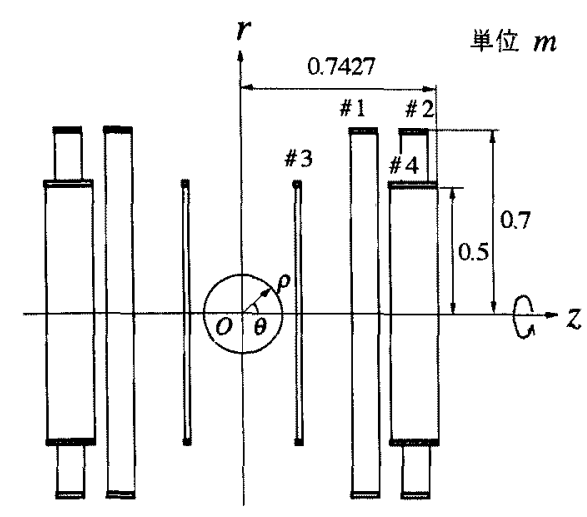

図16勾配磁界遮蔽用4対コイル磁気シールドのコイル 配置例

Fig.16 Example of coil configulation of four pairs coil system for shielding first order gradient field

第3表 zの一次勾配磁界遮蔽用4対コイルの諸元例

Table 1 Example of coil parameters of four pairs coil system for gradient field shielding

\begin{tabular}{cccccc}
\hline \hline コイル & $\begin{array}{c}\text { 半径 } a_{i} \\
(\mathrm{~m})\end{array}$ & $\begin{array}{c}\text { 中心 } z_{i} \\
(\mathrm{~m})\end{array}$ & $\begin{array}{c}\text { 長さ } w_{i} \\
(\mathrm{~m})\end{array}$ & 巻数 & $\begin{array}{c}\text { 誘起電流 } \\
(\mathrm{A} / \mathrm{m} \mathrm{m})\end{array}$ \\
\hline$\# 1$ & 0.70 & 0.46457 & 0.10 & 59 & -10.306 \\
$\# 2$ & 0.70 & 0.65522 & 0.10 & 69 & -10.306 \\
$\# 3$ & 0.50 & 0.21045 & 0.02 & 20 & -10.306 \\
$\# 4$ & 0.50 & 0.65269 & 0.18 & 204 & -10.306 \\
\hline
\end{tabular}

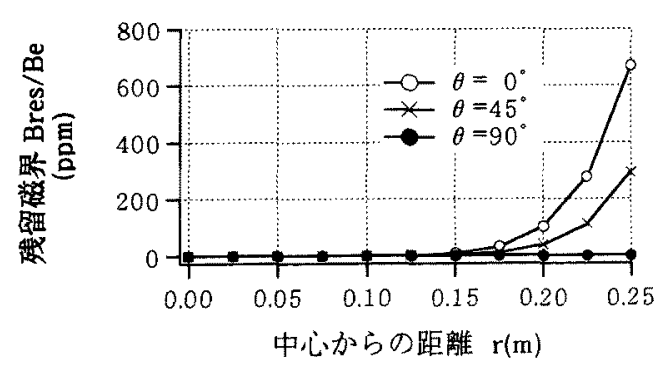

图17勾配磁界遮蔽用4対コイル磁気シールドの 残留磁界(Bres/Be)

Fig.17 Residual field (Bres/Be) of four pairs coil system for shielding gradient magnetic field of first order
決定法を示した。また、本法を用いて、空間分布が座標に よらない一様磁界、および軸方向座標に比例する一次勾配 磁界に対する遮蔽コイルの解析例を示し、超電導ソレノイ ドコイルで構成された巻線系で軸方向磁界の遮蔽効果が得 られることを示した。また、雨端開放超電導円筒シールド との比較を示し、一様磁界抢よび一次勾配磁界の何れに対 しても、超電導円筒シールドに比べて、短尺で高い遮蔽率 が得られることを示した。また、一様磁界および一次勾配 磁界が重畳した複合磁界を遮蔽するための遮蔽巻線の構成 法について述べた。なお、本稿では、空間分布が軸方向座 標のみに依存し、一軸方向成分のみを有する磁界の遮蔽に ついて述べたが、微弱磁界計測では、通常、三軸方向の磁 気遮蔽が必要である。これについては、鞍型コイル、超電 導シートまたは超電導円筒などを併用することによって、 一軸方向磁界のみならず、三軸方向磁界を遮蔽する方法を 検討中であり、別途報告の予定である。

(平成 7 年 2 月 27 日受付, 同 8 年 7 月 3 日再受付)

\section{文 献}

(1)星野和文:「高温超電導体磁気シールド装置とその応 用」，電学論D,113巻8号,947-949(平5)

(2)松葉博則: 「超電導磁気シールド」, 低温工学, 30 巻, 1 号 p3.8 (1995)

(3)矢原昭人、入澤大逸、今井久美子、松葉博則:「酸化物 超電導体を用いた微弱磁場用磁気シールド体の特性」， 電気学会マグネティクス研究会,MAG-90-86 (1990)

(4)Z.X.Feng :"DISTRIBUTION OF SHIELDING CURRENTS IN A CYLINDRICAL SUPERCONDUCTING TUBE", IEEE Trans. on Magnetics, MAG-21, p993-996 (1985)

(5)G.Gabrielse and J.Tan:"Self-shielding superconducting solenoide systems", Appl.Phys.p5143-5148 (May 1988)

(6) 松本和健、藤岡耕治、倉阔泰郎:「SQUID磁束計に基づ いたアクティブシールド」, 電気学会静上器研究会, MAG-92.84 (1992)

(7) D. B. Montgomery and R. J. Weggel: "Solenoid Magnet Design", Robert E. Hrieger publishing company (1980)

第4表 勾配磁界遮蔽用4対コイルの残留磁界 $(\Delta \mathrm{Bres} / \Delta \mathrm{Be})$

軸上 $2=0.15 \mathrm{~m}$ における残留磁界の印加磁界に対する比

Table 4 Residual field ( $\Delta \mathrm{Bres} / \Delta \mathrm{Be}$ ) at $\mathrm{z}=0.15 \mathrm{~m}$ of four pairs coil system

\begin{tabular}{lrlrrrl}
\hline \hline コイル & \multicolumn{1}{c}{ 3次成分 } & \multicolumn{1}{c}{ 5次成分 } & \multicolumn{1}{c}{ 7次成分 } & \multicolumn{1}{c}{ 9次成分 } & \multicolumn{1}{c}{11 次成分 } & 合成值 \\
\hline$\# 1$ & $2.56 \mathrm{E}+00$ & $1.02 \mathrm{E}-01$ & $-6.36 \mathrm{E}-03$ & $4.97 \mathrm{E}-05$ & $6.27 \mathrm{E}-06$ & \\
$\# 2$ & $-5.64 \mathrm{E}-01$ & $1.05 \mathrm{E}-01$ & $1.02 \mathrm{E}-04$ & $-7.96 \mathrm{E}-05$ & $2.63 \mathrm{E}-07$ & \\
$\# 3$ & $1.62 \mathrm{E}+01$ & $-8.24 \mathrm{E}-01$ & $-2.91 \mathrm{E}-02$ & $9.51 \mathrm{E}-03$ & $-9.00 \mathrm{E}-04$ & \\
$\# 4$ & $-2.23 \mathrm{E}+01$ & $5.66 \mathrm{E}-01$ & $4.50 \mathrm{E}-02$ & $-1.23 \mathrm{E}-04$ & $-6.56 \mathrm{E}-05$ & \\
\hline 合計 & $0.00 \mathrm{E}+00$ & $0.00 \mathrm{E}+00$ & $0.00 \mathrm{E}+00$ & $9.38 \mathrm{E}-06$ & $9.47 \mathrm{E}-07$ & $8.43 \mathrm{E}-06$ \\
\hline
\end{tabular}




\section{付録 1 磁界展開係数 $\varepsilon_{n}$}

本文図 2 に示す半径 $a_{i}$ 、中心 $z_{i}$ 、幅 $w_{i}$ のソレノイドの軸 上磁界は次式で与えられる。

$$
B_{i z}(z)=\frac{\mu_{0} j_{i}}{2} \cdot\left\{F\left(u_{i}, \beta_{2 i}\right)-F\left(u_{i}, \beta_{1 i}\right)\right\}
$$

ただし、 $j_{i}$ を電流密度とし

$$
\begin{aligned}
& F(u, \beta)=\frac{\beta-u}{\sqrt{1+(\beta-u)^{2}}} \\
& u_{i}=\frac{z}{a_{i}}, \quad \beta_{2 i}=\frac{z_{i}+w_{i} / 2}{a_{i}}, \quad \beta_{1 i}=\frac{z_{i}-w_{i} / 2}{a_{i}}
\end{aligned}
$$

とする。

原点における $B_{i z}(z)$ のテーラー展開は

ここに

$$
B_{i z}(z)=\frac{\mu_{0} j_{j}}{2} \sum_{k=0}^{\infty} \varepsilon_{i k}\left(\frac{z}{a_{i}}\right)^{k}
$$

であり、

$$
\varepsilon_{i k}=\frac{2}{\mu_{0} j_{i}} \cdot \frac{a_{i}^{k}}{k !} \cdot\left[\frac{\partial^{k} B_{i z}(z)}{\partial z^{k}}\right]_{z=0}
$$

$$
f_{k}(\beta)=\frac{1}{k !} \cdot\left[\frac{\partial^{k} F(u, \beta)}{\partial u^{k}}\right]_{u=0}
$$

とおけば、 $\varepsilon_{i k}$ は次式で求められる。

$$
\varepsilon_{i k}=f_{k}\left(\beta_{2 i}\right)-f_{k}\left(\beta_{1 i}\right)
$$

$f_{n}(\beta)$ の次までの表式は次の通りである。

$$
\begin{aligned}
& f_{0}(\beta)=\frac{\beta}{\sqrt{1+\beta^{2}}} \\
& f_{1}(\beta)=-\frac{1}{\left(1+\beta^{2}\right)^{3 / 2}} \\
& f_{2}(\beta)=\frac{-3 \beta}{2\left(1+\beta^{2}\right)^{5 / 2}} \\
& f_{3}(\beta)=\frac{1-4 \beta^{2}}{2\left(1+\beta^{2}\right)^{7 / 2}} \\
& f_{4}(\beta)=\frac{5 \beta\left(3-4 \beta^{2}\right)}{8\left(1+\beta^{2}\right)^{9 / 2}} \\
& f_{5}(\beta)=\frac{3\left(-1+12 \beta^{2}-8 \beta^{4}\right)}{8\left(1+\beta^{2}\right)^{1 / 2}} \\
& f_{6}(\beta)=\frac{7 \beta\left(-5+20 \beta^{2}-8 \beta^{4}\right)}{16\left(1+\beta^{2}\right)^{13 / 2}}
\end{aligned}
$$

\section{付録2 基本方程式の求解法}

本文(35)式の導出法を示す。

本文(32)式および(34)式において

$$
\begin{aligned}
& \mathbf{x}={ }^{\prime}\left[X_{1}, X_{2}, \cdots X_{n-1}, X_{n}\right] \\
& \hat{\mathbf{x}}={ }^{t}\left[X_{1}, X_{2}, \cdots X_{n-1}\right] \\
& \mathbf{m}={ }^{t}\left[-B_{0},-B_{2}, \cdots,-B_{2 n-4}\right]
\end{aligned}
$$

$$
\mathbf{H}=\left|\begin{array}{cccc}
h_{0,1} & h_{0,2} & \cdots & h_{0, n-1} \\
h_{2,1} & h_{2,2} & & h_{2, n-1} \\
\vdots & & \ddots & \vdots \\
h_{2 n-4,1} & h_{2 n-4,2} & \cdots & h_{2 n-4, n-1}
\end{array}\right|
$$

$$
\mathbf{h}_{n}={ }^{\prime}\left[h_{n, 0}, h_{n, 2}, \cdots, h_{n, 2 n-4}\right]
$$

$$
\mathbf{K}=\left[\begin{array}{cccc}
k_{11} & k_{12} & \cdots & k_{1 n} \\
k_{21} & k_{22} & & k_{2 n} \\
\vdots & & \ddots & \vdots \\
k_{n 1} & k_{n 2} & \cdots & k_{n n}
\end{array}\right]
$$$$
\mathrm{s}={ }^{t}\left[\begin{array}{llll}
\phi_{1} & \phi_{2} & \cdots & \phi_{n}
\end{array}\right]
$$

とおくと(32)式および(34)式は

$$
\begin{aligned}
& \mathbf{H} \hat{\mathbf{x}}=-\mathbf{h}_{n} X_{n}+\mathbf{m} \\
& { }^{t} \mathbf{x K x}+{ }^{t} \mathbf{s} \mathbf{x}=0
\end{aligned}
$$

(付 22)式より $\hat{\mathbf{x}}$ は $X_{n}$ で表すことができて

ただし

$$
\hat{\mathbf{x}}=\hat{\mathbf{a}} X_{n}+\hat{\mathbf{b}}
$$

とする。ここで

$$
\mathbf{a}={ }^{\prime}\left[\hat{a}_{1}, \hat{a}_{2}, \cdots, \hat{a}_{n-1}, 1\right]
$$

$$
\mathbf{b}='\left[\hat{b}_{1}, \hat{b}_{2}, \cdots, \hat{b}_{n-1}, 1\right]
$$

とおけば、(付15)(付16)抢よび(付24)式より

$$
\mathbf{x}=\mathbf{a} X_{n}+\mathbf{b}
$$

これを(付23)式に代入すれば

$$
\left[X_{n}{ }^{\prime} \mathbf{a}+{ }^{\prime} \mathbf{b}\right][\mathbf{K}]\left[\mathbf{a} X_{n}+\mathbf{b}\right]+{ }^{t}[\mathbf{s}]\left[\begin{array}{ll}
\mathbf{a} & \left.X_{n}+\mathbf{b}\right]=0
\end{array}\right.
$$

これを展開することにより、(付23)式は $X_{n}$ に関する次の2 次方程式に帰着される。

$A X_{n}{ }^{2}+B X_{n}+C=0$

$A={ }^{t}[\mathbf{a}][\mathbf{K}][\mathbf{a}]$

(付 32)

$B={ }^{t}[\mathbf{b}][\mathbf{K}][\mathbf{a}]+{ }^{t}[\mathbf{a}][\mathbf{K}][\mathbf{b}]+{ }^{t}[\mathbf{s}][\mathbf{a}]$

(付33

$C=t[\mathbf{b}][\mathbf{H}][\mathbf{b}]+{ }^{t}[\mathrm{~s}][\mathbf{b}]$

(付34)
武智盛明

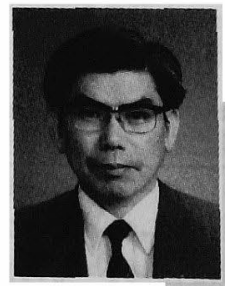

(正員)昭和 14 年 3 月 23 日生。昭和 38 年 3 月東京大学工学部電気工学科卒業。 同年 4 月三菱電機入社。電力用変圧器、 磁気共鳴イメージング装置用超電導マ グネットの開発設計に従事。 